\title{
Schuminszky Nándor
}

\section{Repül a SpaceX Falcon-9-es rakétája}

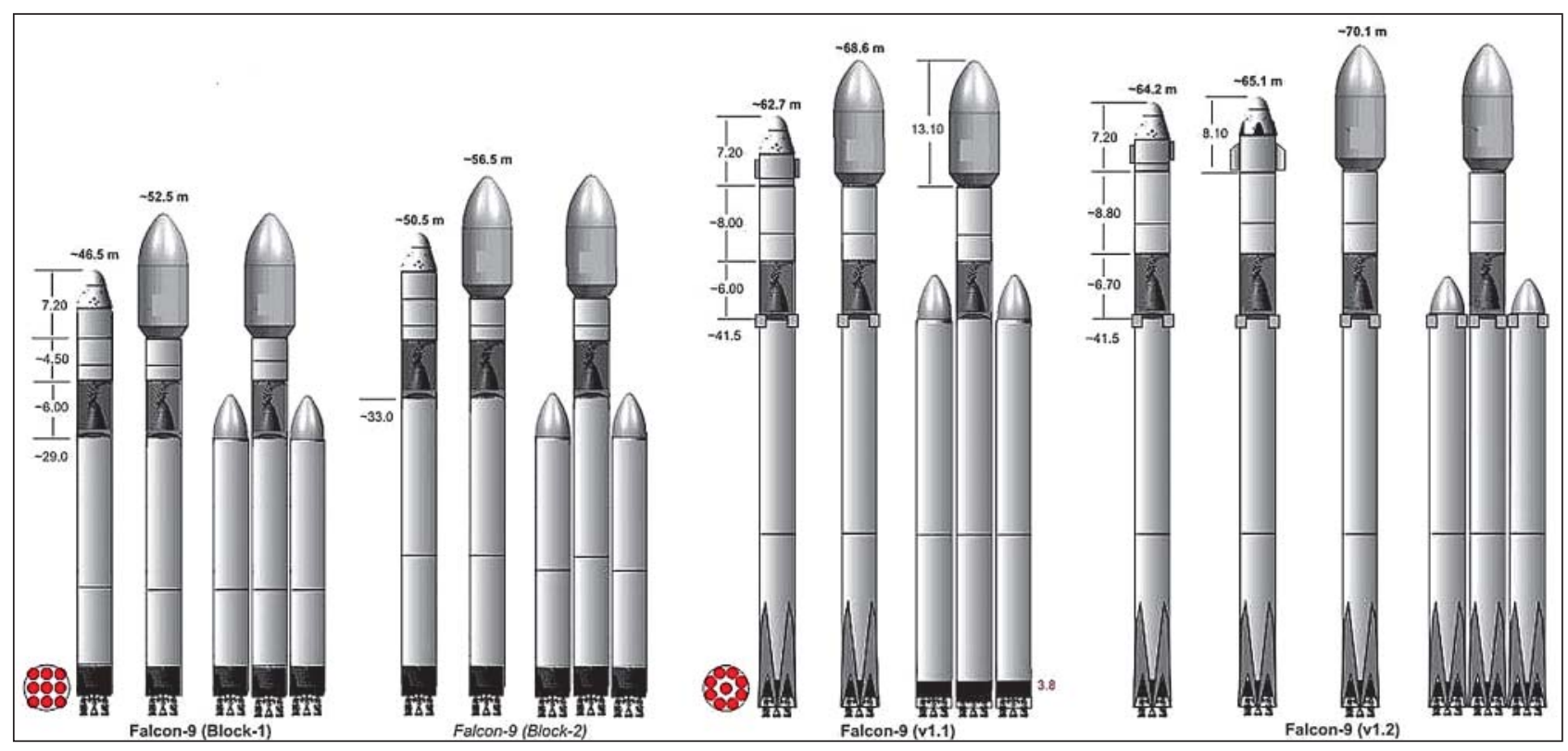

1. ábra. A komplett Falcon-család. Az első fokozat hajtómú-elrendezése a Block-1-estől (három soros) kezdve megváltozott körkörösre. A középső hajtómú biztosítja a leszállást (Space Launch Vehicles)

A z űrkutatás jellege a XXI. század elején kezdett megváltozni. A nem állami vállalatok egyre nagyobb szeletet követeltek és követelnek maguknak az „ürtortából”. Ezek a cégek az űrkutatás eredményeit felhasználva, a gazdasági folyamatokra helyezték a hangsúlyt. Az ún. űrturizmus is jelentős hasznot hajtott a vállalkozó cégeknek, de az igazi nagy üzlet a saját ürhajók és saját hordozórakéták kifejlesztésében rejlett. A NASA szerződéseiért versengő űripari cégek közül is kiemelkedik a SpaceX, rendkívüli vezérigazgatója, Elon Musk vezetésével. A Haditechnika korábbi számaiban már foglalkoztunk a Falconnal (Fél percig repült a Sólyom, HT 2006/5., „A Sárkány éve”, HT 2011/3., A Dragon próbarepülése, HT 2012/3., „A Dragon-C2 ürrepülése", HT 2013/1), ezért most - a táblázatok kivételével - csak az azóta történt eseményeket követjük.

\section{Megszületik az úJ Falcon}

A Falcon-9-es folyékony hajtóanyagú hordozórakétát a SpaceX (Space Exploration Technologies Corporation) fejlesztette ki közepes és nehéz változatban. Ebben a ka- tegóriában újdonságnak számított, hogy az első fokozat potenciálisan újra felhasználható volt a B1, illetve a v1.0 sorozatban. (A Space Shuttle gyorsítórakétája szilárd hajtóanyagot tartalmazott.) A továbbfejlesztés során - Falcon-9 v1.1 - megvalósították a hajtóműves leszállást az ejtőernyős módszer helyett, és ezekbe a típusokba a SpaceX által épített Merlin-1D hajtóművek kerültek a Merlin-1C felváltására, regeneratív hütéssel. A második fokozat egyetlen Merlin-1D hajtómúvet tartalmaz. A Falcon-9es orrkúpja 3,10 × 5,20 m méretű. A Falcon-9-es v1.2 rakétába pedig a 16\%-kal erősebb Merlin-1D+ került beszerelésre. Ennél is újdonságnak számít, hogy a vákuumban bekapcsoló Merlin 1D+ meghosszabbított fúvóka-kialakítással rendelkezik, ami további 1\%-os tolóerő növekedést ad. Az új hajtóművek rugalmasabb küldetési profilt biztosítanak a beépített fojtószelepek segítségével. A korábbi Merlin-változatok vagy nem rendelkeztek ilyen szelepekkel, vagy nem használták azokat; két teljes hajtóművet kellett leállítani a művelet végrehajtásához. A hajtóanyagtartályok kapacitása is megnövekedett az alkalmazott hűtés változása következtében. A folyékony oxigén most $\mathrm{kb} .23^{\circ} \mathrm{C}-\mathrm{kal}$ lett hidegebb, mint a forráspontja, ami nagy-
ÖSSZEFOGLALÁS: Egyéb üzleti tevékenysége után, a Falcon (Sólyom) rakéta alapozta meg Elon Musk világhírnevét. A SpaceX rakétája ma már a NASA szerződésében szolgál, nemsokára a Dragon ürhajóval nemcsak utánpótlást, hanem ürhajósokat is fog szállitani a Nemzetközi UÚrállomásra.

KULCSSZAVAK: ürkutatás, SpaceX, Falcon-9, hordozórakéta, polgári ürrepülés
ABSTRACT: Following his activities in other business fields, it was the Falcon rocket that established Elon Musk's international reputation. The rocket of the SpaceX company servicing now NASA under a contract will transport soon not only new supplies but also astronauts to the International Space Station, using the Dragon spacecraft.

KEY WORDS: space research, SpaceX, Falcon-9, launching rocket, civil spaceflight 


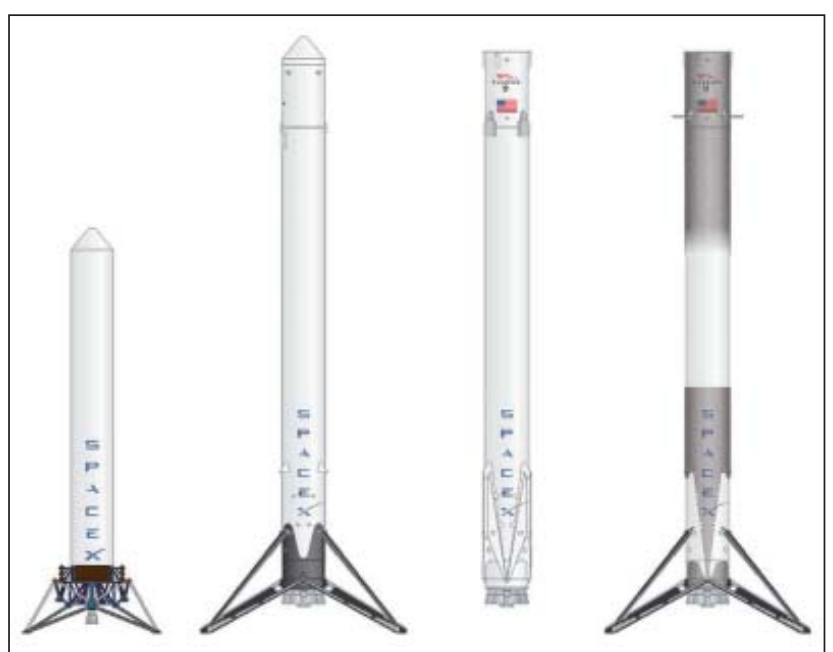

2. ábra. Az első fokozat visszatérési próbáihoz használt példányok. A Falcon-9-es hajtómúves visszatérési változatai, balról:

„Szöcske” - csak kis magasságú, „földi” próba,

Falcon-9-es „Full-Thrust” tesztpéldány,

Falcon-9 FT starthelyzetben (leszállólábak zárt állapotban), Falcon-9 FT visszatérési helyzetben (leszállólábak nyitott állapotban)

jából 9\%-os sűrűség-növekedést eredményezett. A kerozin kevésbé hűl le; $-6^{\circ} \mathrm{C}$ hőmérsékleten a sűrűsége körülbelül 2\%-kal nő. A második fokozat kb. 1,6 m-rel, a két fokozat közötti gyűrű pedig kb. 0,8 m-rel lett hosszabb.

Az újra felhasználható 1. fokozat 2016. április 8-a után, 2017. március 30-án indult másodszor a világűrbe, és sike- resen vissza is tért a Földre. (A 2. táblázatban a szériaszám utáni szám jelenti, hogy hányszor használták fel.)

2015 januárjában Martin Halliwell, a SES (Société Européenne des Satellites, Európai Mühold Társaság) müszaki vezérigazgatója jelentette be, hogy az ő műholdjuk - SES-9-es - fog elsőként startolni az új Merlin-1D hajtóművekkel ellátott Falcon-9-es rakétával. Tavaszra azonban megváltozott a helyzet; március 9-én az Aviation Week \& Space Technology címú szaklap számolt be arról, hogy a SES úgy döntött, hogy másnak engedi át az elsőség dicsőségét. A SES-9-es startja előbb 2015 második, később harmadik negyedévére tolódott. Végül 2016. március 4-én sikeresen kijutott a Föld körüli pályára.

2015. március 17-én a SpaceX elnöke, Gwynne Shotwell részletesen beszámolt az újdonságokról, és egyben felajánlotta a frissített rakétát a megrendelőknek. Ő azt mondta, hogy a SES egyszerűen visszalépett az új Merlin-1D extra teljesítményének az igazolásától. Néhányan felfigyeltek arra, hogy a SpaceX elnöke egyetlen egyszer sem mondta ki a rakéta nevét: - Nem tudom, hogyan fogjuk hívni: lehet Enhanced (felfokozott teljesítményú) Falcon 9-es vagy Full-Performance (teljes működésű) Falcon-9es, esetleg „full-thrust” (teljes tolóerejü) Falcon-9-es. A SpaceX elnökének szavai jelezték, hogy a cég még mindig nem döntött véglegesen a rakéta nevéről. A problémát az okozta, hogy ezek a kifejezések nem adták pontosan vissza azt a funkciót, amely az első fokozat hajtóműves visszatérését és leszállását jelentette. Shotwell azt is elmondta, hogy a korszerűsített Falcon-9-es első fokozatát fogják a Falcon Heavy oldalsó rakétájaként is felhasználni, de a központi magja másfajta lesz.

2015 nyarán a SpaceX továbbra is ingadozott a rakéta nevével kapcsolatban; az egyik bemutatón „Falcon-9 Up-

\section{3. ábra. A Falcon-9-es repülési, és az első fokozatának visszatérési profilja (SpaceX)}

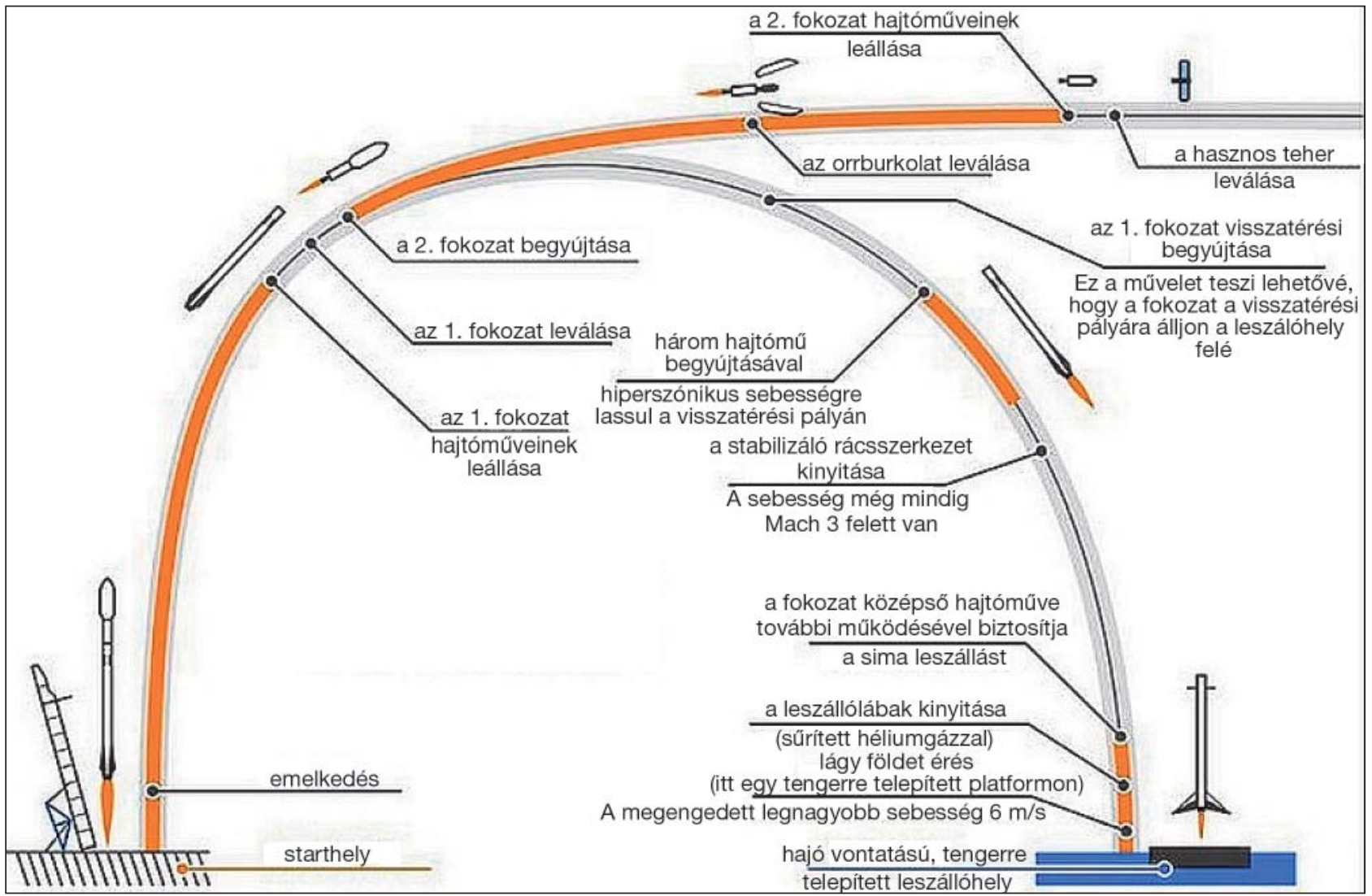


1. táblázat. A Falcon-9-es rakéta fokozatai és hajtómúvei (Space Launch Vehicles)

\begin{tabular}{|c|c|c|c|c|c|c|}
\hline \multirow{2}{*}{$\begin{array}{c}\text { Falcon-9 } \\
\text { alap }\end{array}$} & \multicolumn{2}{|c|}{ Falcon-9 Heavy } & \multicolumn{2}{|c|}{ 1. fokozat } & \multicolumn{2}{|c|}{ 2. fokozat } \\
\hline & Darab/Név & Darab/Típus & Darab/Név & Darab/Típus & Darab/Név & Darab/Típus \\
\hline Block-1 & $2 \mathrm{db} L-254$ & $9 \mathrm{db}$ Merlin-1C & $1 \mathrm{db} L-254$ & $9 \mathrm{db}$ Merlin-1C & $1 \mathrm{db} L-55$ & $1 \mathrm{db}$ Merlin-1CV \\
\hline Block-2 & $2 \mathrm{db} L-254$ & $9 \mathrm{db}$ Merlin-1C & $1 \mathrm{db} L-310$ & $9 \mathrm{db}$ Merlin-1C+ & $1 \mathrm{db} L-55$ & $1 \mathrm{db}$ Merlin-1C+V \\
\hline v1.1 & $2 \mathrm{db} L-389$ & $9 \mathrm{db}$ Merlin-1D & $1 \mathrm{db} L-388$ & $9 \mathrm{db}$ Merlin-1D & $1 \mathrm{db} L-89$ & $1 \mathrm{db}$ Merlin-1DV \\
\hline $\mathrm{v} 1.2$ & $2 \mathrm{db} L-393$ & $9 \mathrm{db}$ Merlin-1D+ & $1 \mathrm{db} L-393$ & $9 \mathrm{db}$ Merlin-1D+ & $1 \mathrm{db} L-109$ & $1 \mathrm{db}$ Merlin-1D+V \\
\hline
\end{tabular}

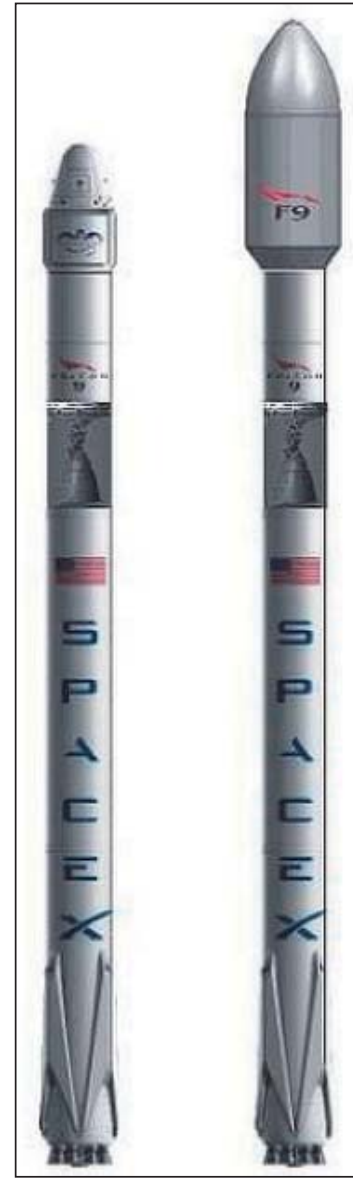

4. ábra. A Falcon-9 v1.2 rakéta két változata: a bal oldali a Dragon ürhajóval, a jobb oldali a megnövelt orrkúppal (ex) látható (SpaceX) időtartamú vizsgálatot november 19-én végezték el. A második fokozat próbája november 22-én zajlott le.

A bevizsgált első fokozat november 20 -án reggel érkezett meg Cape Canaveral-re. Alig egy hónappal később, december 18-án az összeszerelt, komplett rakétával az Orbcomm-G2-es műholddal a tetején, egy rövid égetési próbát végeztek a 40 -es indítóálláson. Egy váratlan hiba a földi rendszerre terelte a szakemberek gyanúját, ami a kiértékelés során be is igazolódott. A hiba okát abban jelölték meg, hogy a statikus próba az indítópadon alaposan megrázta az új szuperhűtő berendezést.

Ezt a hűtőberendezést és a rakétát szállító-emelő eszközt két helyre telepítették a Falcon-9 v1.2 és a tervezett Falcon Heavy részére; Vandenberg AFB, SLC-4E (Space Launch Complex, East) és Cape Canaveral LC-39/A. Ez

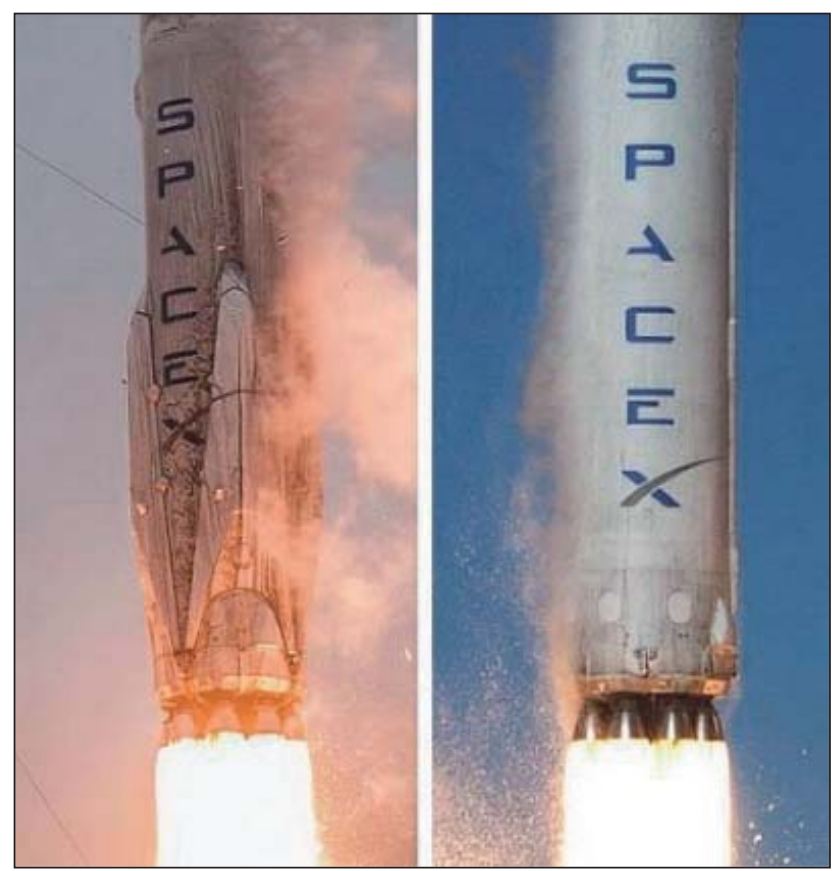

5. ábra. A hajtómúves visszatérésre alkalmas első fokozat (bal) és a korábbi változat emelkedés közben (SpaceX)

utóbbi, legendás startkomplexumot (Apollo, Space Shuttle) teljes egészében átépítették mindkét típus részére. Ezeken kívül további változást jelent a Kennedy Ürközpontban egy új, vízszintes szerelőcsarnok - inkább hangár - felépítése. Innen egy pár vasúti sín vezet az indítópadhoz, azon az

\section{6. ábra. Falcon-9 v1.2 interstage a HIF hangárban (SpaceX)}

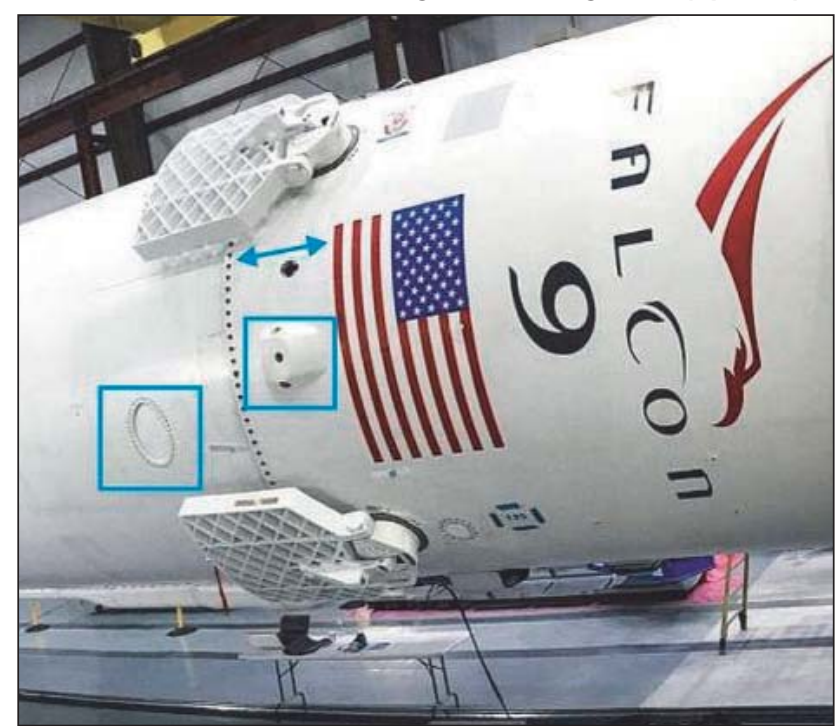


2. táblázat. A Falcon-9-es rakéta starttáblázata

\begin{tabular}{|c|c|c|c|c|c|c|}
\hline Sor.össz. & Sor.típ. & Típus & Szériaszám & Dátum & Starthely & 1. fokozat visszatérés \\
\hline 1 & 1 & Falcon-9 v1.0 & B0003 & 2010.06 .04 & CC SLC-40 & kudarc (ejtőernyős) \\
\hline 2 & 2 & Falcon-9 v1.0 & - & 2010.12 .08$. & CC SLC-40 & kudarc (ejtőernyős) \\
\hline 3 & 3 & Falcon-9 v1.0 & - & 2012.05 .22 & CC SLC-40 & nem tervezett \\
\hline 4 & 4 & Falcon-9 v1.0 & - & 2012.10.08. & CC SLC-40 & nem tervezett \\
\hline 5 & 5 & Falcon-9 v1.0 & - & 2013.03.01. & CC SLC-40 & nem tervezett \\
\hline 6 & 1 & Falcon-9 v1.1(ex) & - & 2013.09.29. & Va SLC-4E & kudarc \\
\hline 7 & 2 & Falcon-9 v1.1(ex) & - & 2013.12.03. & CC SLC-40 & nem tervezett \\
\hline 8 & 3 & Falcon-9 v1.1(ex) & - & 2014.01 .06$. & CC SLC-40 & nem tervezett \\
\hline 9 & 1 & Falcon-9 v1.1 & - & 2014.04 .18$. & CC SLC-40 & siker \\
\hline 10 & 2 & Falcon-9 v1.1 & - & 2014.07.14. & CC SLC-40 & siker \\
\hline 11 & 4 & Falcon-9 v1.1 (ex) & - & 2014.08 .05$. & CC SLC-40 & nem tervezett \\
\hline 12 & 5 & Falcon-9 v1.1 (ex) & - & 2014.09 .07$. & CC SLC-40 & nem tervezett \\
\hline 13 & 6 & Falcon-9 v1.1 (ex) & - & 2014.09.21. & CC SLC-40 & siker \\
\hline 14 & 3 & Falcon-9 v1.1 & - & 2015.01 .10$. & CC SLC-40 & kudarc \\
\hline 15 & 4 & Falcon-9 v1.1 & - & 2015.02 .11$. & CC SLC-40 & siker \\
\hline 16 & 7 & Falcon-9 v1.1 (ex) & - & 2015.03 .02$. & CC SLC-40 & nem tervezett \\
\hline 17 & 5 & Falcon-9 v1.1 & - & 2015.04 .14$. & CC SLC-40 & kudarc \\
\hline 18 & 8 & Falcon-9 v1.1 (ex) & - & 2015.04 .27$. & CC SLC-40 & nem tervezett \\
\hline 19 & 6 & Falcon-9 v1.1 & - & 2015.06 .28 & CC SLC-40 & $T+2$ perckor felrobbant \\
\hline 20 & 1 & Falcon-9 v1.2 & B1019-1 & 2015.12 .22$. & CC SLC-40 & siker \\
\hline 21 & 7 & Falcon-9 v1.1 & - & 2016.01 .17$. & Va SLC-4E & kudarc \\
\hline 22 & 2 & Falcon-9 v1.2 & B1020-1? & 2016.03 .04$. & CC SLC-40 & kudarc \\
\hline 23 & 3 & Falcon-9 v1.2 & B1021-1 & 2016.04 .08$. & CC SLC-40 & siker \\
\hline 24 & 4 & Falcon-9 v1.2 & B1022-1 & 2016.05 .06$. & CC SLC-40 & siker \\
\hline 25 & 5 & Falcon-9 v1.2 & B1023-1 & 2016.05 .27$. & CC SLC-40 & siker \\
\hline 26 & 6 & Falcon-9 v1.2 & B1024-1? & 2016.06 .15$. & CC SLC-40 & kudarc \\
\hline 27 & 7 & Falcon-9 v1.2 & B1025-1 & 2016.07.18. & CC SLC-40 & siker \\
\hline 28 & 8 & Falcon-9 v1.2 & B1026-1? & 2016.08 .14$. & CC SLC-40 & siker \\
\hline 29 & 9 & Falcon-9 v1.2 & B1028-1? & 2016.09 .01$. & CC SLC-40 & felrobbant a padon \\
\hline 30 & 10 & Falcon-9 v1.2 & B1029-1 & 2017.01 .14$. & Va SLC-4E & siker \\
\hline 31 & 11 & Falcon-9 v1.2 & B1031-1 & 2017.02.19. & CC LC-39A & siker \\
\hline 32 & 1 & Falcon-9 v1.2 (ex) & $\mathrm{B} 1030$ & 2017.03 .16 & CC LC-39A & nem tervezett \\
\hline 33 & 12 & Falcon-9 v1.2 & B1021-2 & 2017.03.30. & CC LC-39A & siker \\
\hline 34 & 13 & Falcon-9 v1.2 & B1032-1 & 2017.05 .01$. & CC LC-39A & siker \\
\hline 35 & 2 & Falcon-9 v1.2 (ex) & B1034 & 2017.05 .15$. & CC LC-39A & nem tervezett \\
\hline 36 & 14 & Falcon-9 v1.2 & B1035-1 & 2017.06.03. & CC LC-39A & siker \\
\hline 37 & 15 & Falcon-9 v1.2 & B1029-2 & 2017.06.23. & CC LC-39A & siker \\
\hline 38 & 16 & Falcon-9 v1.2 & B1036-1 & 2017.06.25. & Va SLC-4E & siker \\
\hline 39 & 3 & Falcon-9 v1.2 (ex) & B1037 & 2017.07.05. & CC LC-39A & nem tervezett \\
\hline 40 & 17 & Falcon-9 v1.2 & B1039-1 & 2017.08 .14$. & CC LC-39A & siker \\
\hline 41 & 18 & Falcon-9 v1.2 & B1038-1 & 2017.08 .24$. & Va SLC-4E & siker \\
\hline 42 & 19 & Falcon-9 v1.2 & B1040-1 & 2017.09 .07$. & CC LC-39A & siker \\
\hline \multicolumn{7}{|c|}{ Tervezett indítások: } \\
\hline & & Falcon-9 v1.2 & - & 2017.10 .02 & Va SLC-4E & tervezett \\
\hline & & Falcon-9 v1.2 & B1031-2 & 2017.10.04. & CC LC-39A & tervezett \\
\hline
\end{tabular}

Rövidítések: ex = nem újra felhasználható CC = Cape Canaveral; Va = Vandenberg AFB 


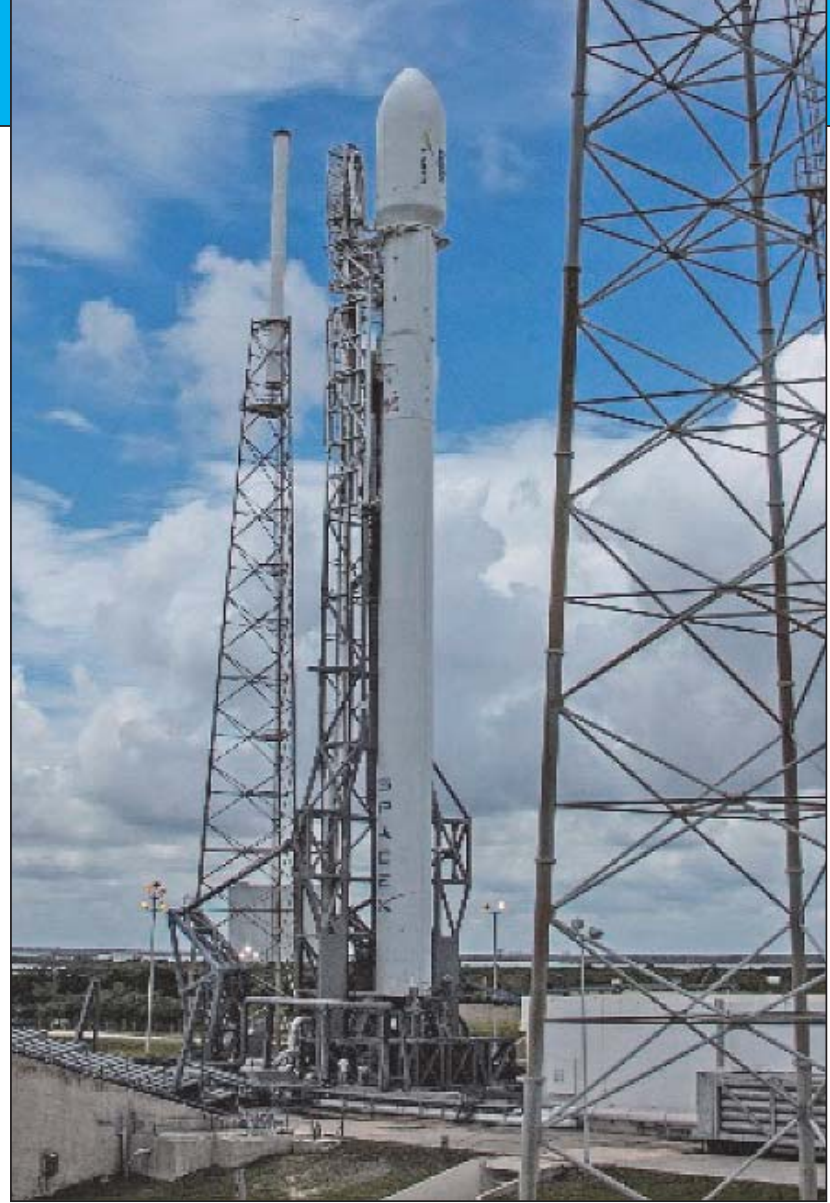

7. ábra. Cape Canaveral SLC-40-es (SpaceX)

8. ábra. Startol a Falcon-9 v1.1 rakéta 2014.09.07-én (SpaceX)

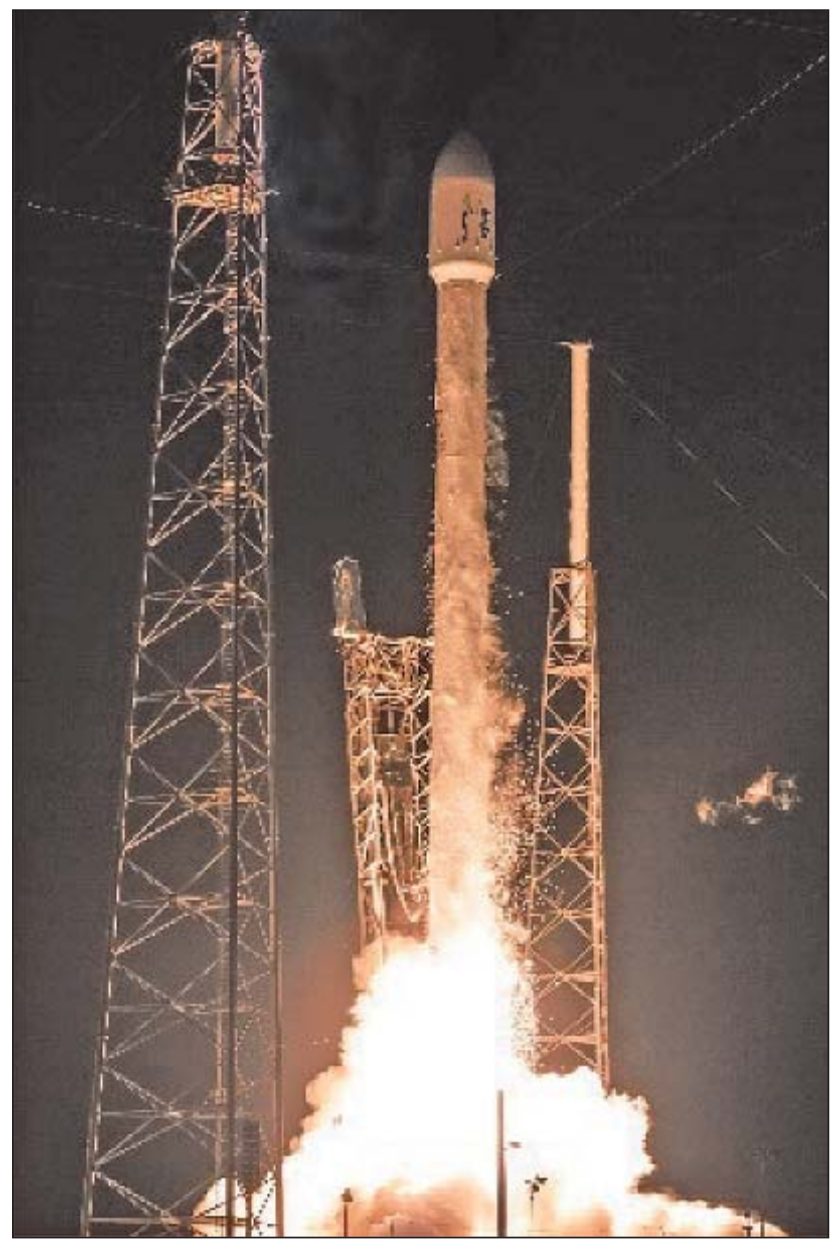

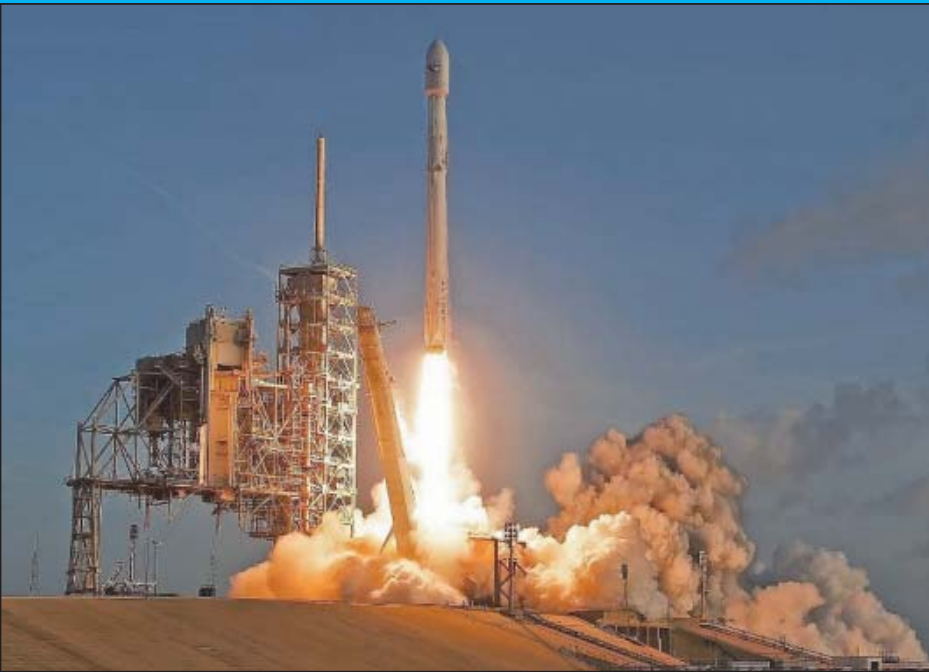

9. ábra. Már a legendás LC-39A startkomplexumról is indulnak Falcon rakéták (America Space)

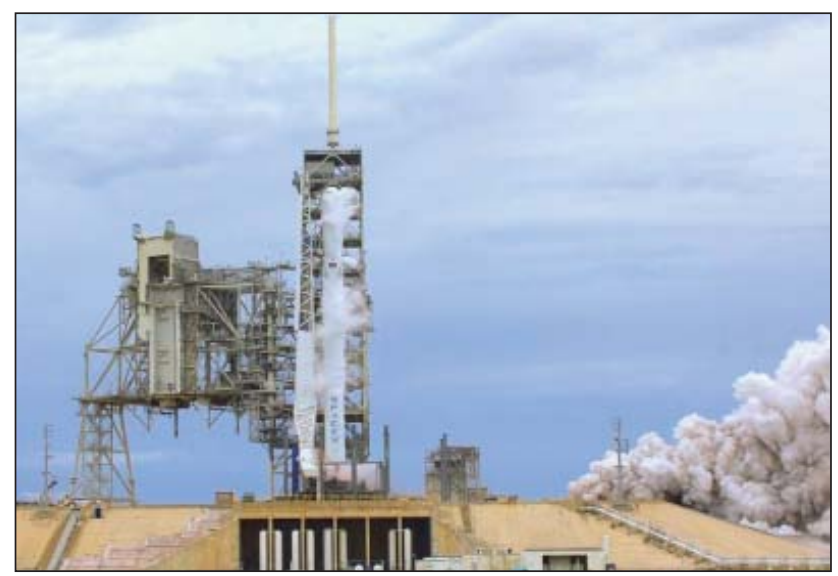

10. ábra. Az X-37B katonai mini ürrepülögépet az eddigi négy alkalommal Atlas-V rakéta vitte fel Föld körüli pályára. $A z$ ötödik alkalommal Falcon-9 v1.2 vette át a hordozórakéta szerepét. E sorok írásakor még csak a statikai teszt zajlott Cape Canaveral-en (SpaceX)

úton, amin 2011-ig az űrrepülőgépeket szállító MLP (Mobil Launch Platform, mozgó startasztal) haladt; az 5 km-es utat 9 óra alatt tette meg.

\section{AZ ELSŐ ODA-VISSZA ÚT}

2015. december 22-én, 11 db 172 kg-os Orbcomm mühold várta a Falcon-9 v1.2 rakéta tetején az indulást. A start az SLC 40-ről 01:29 UTC-kor történt. Az SLC-40-et 1965 és 2005 között használták; az USAF 55 db Titan-IIIas és Titan-IV-es rakétát indított onnan. A 69,799 m (229 láb) magas rakéta $6926 \mathrm{kN}$ tolóerejét kilenc Merlin-1D+ hajtómú biztosította. Ez 15\%-kal nagyobb érték a korábbi, v1.1 változaténál. Az első fokozat 140 sec-ig működött, majd 4 sec-cel később levált. A második fokozat a start utáni 155. sec-ben gyújtott be, és közel 8 min-es működés következtében, sikeresen elérte a 620-660 km-es, $47^{\circ}$-os Föld körüli pályát. A $11 \mathrm{db}$ Orbcomm mühold egymás után, a start utáni 15. és 20. min között vált le a középre szerelt tartóoszlopról.

Nagyjából 3 min 50 sec-cel az indítás után következett a nagy esemény. Újból begyújtották az első fokozat hajtómúveit 30 sec-ig, majd kb. 8 min-nel a start után, 20 secig. Mindkét alkalommal csak három hajtóművet használtak a kilencből. Egy utolsó, nagyjából 32 sec-es - csak a középső hajtóművel - de teljes erővel végrehajtott fékezés után, az első fokozat négy leszállólábát kiengedve lassan, 


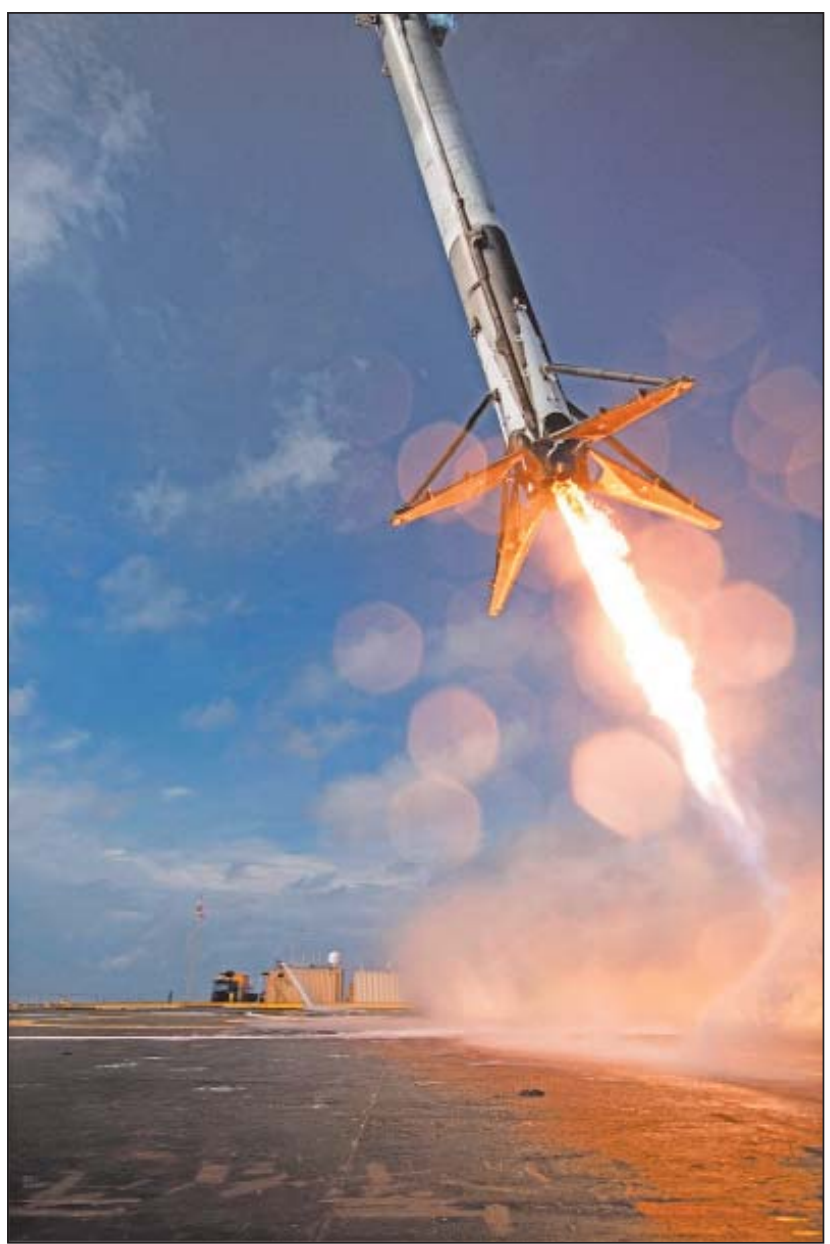

11. ábra. Nem sokkal, 8 perccel a start után már vissza is érkezik az első fokozat (SpaceX)

egy körkörös céltáblára emlékeztető leszállóhely központjához közeledett, majd függőleges helyzetben sikeresen le is szállt. A központi hajtómüből egy kis láng kb. fél percig még továbbra is látható volt, miután a Merlin-1D+ leállt.

A sikeres visszatérés után a leszállóhely platformját hajóval az indítóhelyének közelébe vontatták, és kirakták a Landing Zone 1-esre. Ez, az egykori LC-13-as helyén létesült, ahonnan $51 \mathrm{db}$ Atlas és Atlas-Agena rakéta startolt

12. ábra. Egy sikeresen visszatért első fokozat, 2016. május 6-án (SpaceX)

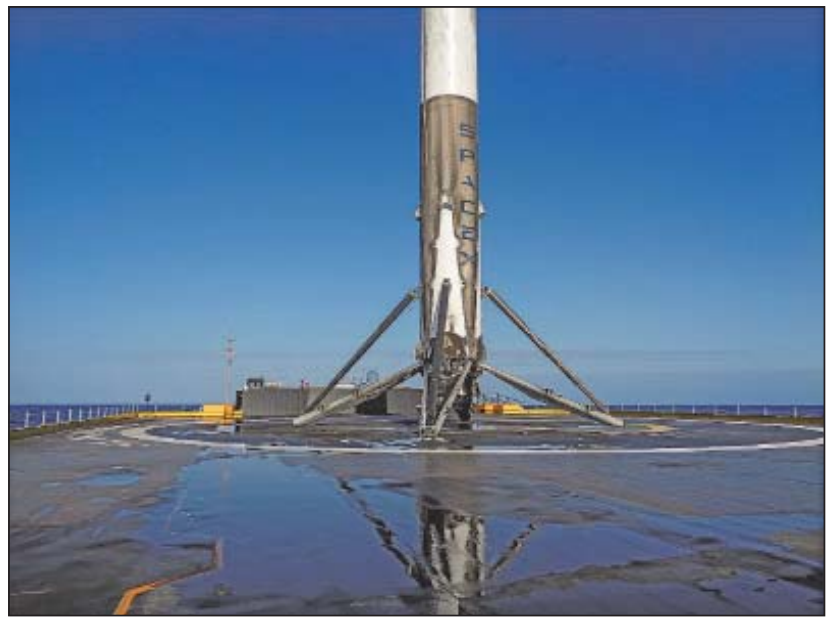

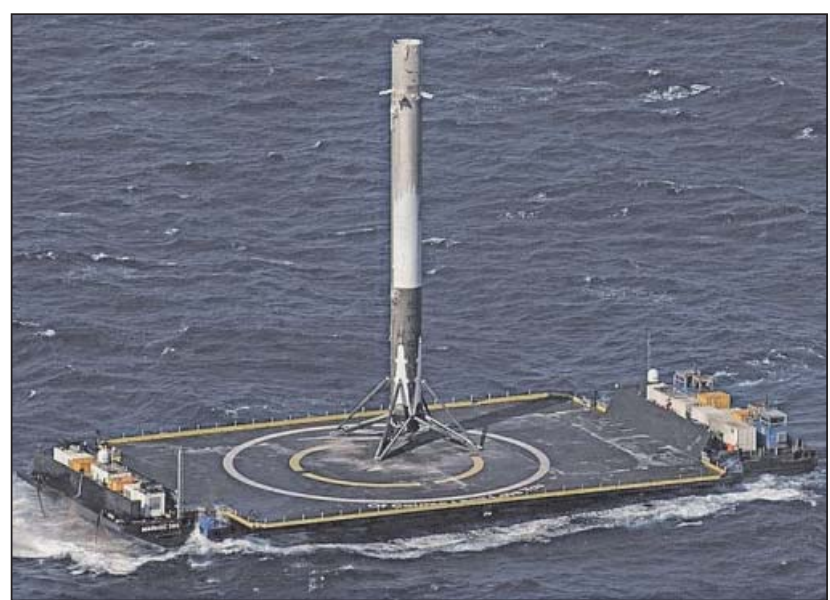

13. ábra. Jól látható, hogy a rakéta milyen pontosan érte el a leszállóhely platformját (SpaceX)

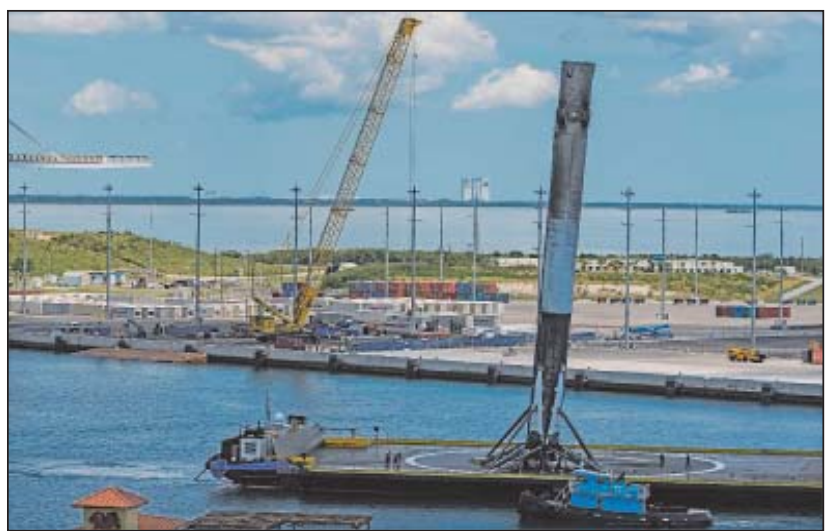

14. ábra. Hajóval az új hangárhoz vontatják az elsó fokozatot, 2016. május 27-én (Amarica Space)

1958-1978 között. A mobil szerviztornyot 2005-ben, a blokkházat 2012-ben bontották le. Ide építette a SpaceX a 86 m (282 láb) átmérőjü leszállóplatformot a koncentrikus körökkel, pontosan oda, ahol a szerviztorony parkolt az Atlas rakéták felemelkedése során.

Elon Musk sajtótájékoztatót tartott, ahol bejelentette, hogy „bár a visszatért első fokozatot újra fel lehetne használni, de erre most nem fog sor kerülni”. Át is szálították az LC-39A új vízszintes összeszerelési csarnokába (Horizontal Integration Facility), ahol fényképezés és állapotfelmérés után, alaposan megvizsgálták. Bár az eredmények nem voltak teljes mértékben kifogástalanok, 2016. január 12-én

15. ábra. A hangárban alaposan átvizsgálják a sikeresen visszatért első fokozatot, amely újra felhasználható (SpaceX)

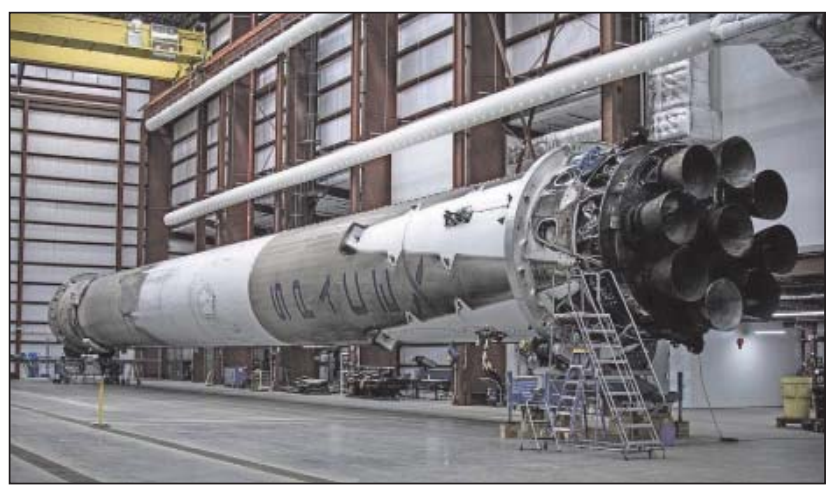




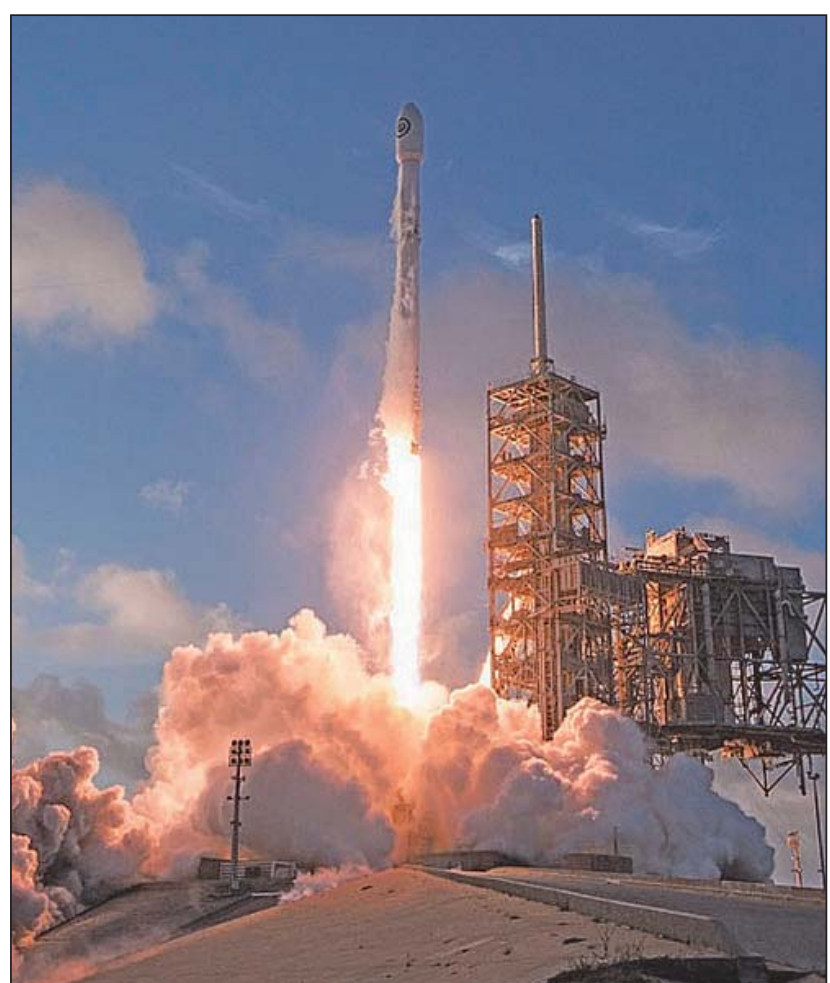

16. ábra. Startol a Falcon-9 v1.2 az NROL-76-os katonai holddal (SpaceX)

- teljesen váratlanul - a fokozatot átszálították az SLC-40esre. A szokásos szállító-emelő szerkezet helyett egy daru állította fel a padra a fokozatot. Két nappal később, egy előre be nem jelentett statikus hajtóműpróbát tartottak, de a kísérletet 2-3 sec elteltével megszakították. Elon Musk, a próba utáni twitter üzenetében az egyik külső hajtómű kimaradásairól adott hírt, „olyan volt, mintha lenyelt volna valamit”. Nem sokkal később a fokozatot visszavitték a HIF hangárba.

\section{MIt hOZHAT A Jövö?}

A Falcon-9-es rakéta sikereit - műholdak, a Dragon teherűrhajó felbocsátása - egy katasztrofális robbanás szakította meg. 2016. szeptember 3-ára tervezték az 5,5 tonnás AMOS-6 távközlési műhold felbocsátását, de két nappal előtte a hajtóanyag-betöltési és tűzoltási próbán tűz ütött ki. A korai jelentések szerint már majdnem végeztek a hajtóanyag betöltésével, amikor körülbelül 13:07-kor (UTC) egy erőteljes robbanás elpusztította a rakétát és a 200 millió dolláros műholdat. A következő percekben kisebb robbanások sorozata lepte el az SLC-40-est, hatalmas tűz tombolását kiváltva. Egy óriási füstcsík sodródott át az egész floridai űrközponton. Ez volt a legnagyobb robbanás indítópadon Cape Canaveral történetében.

Néhány órával a robbanás után Elon Musk twitter üzenetében kifejtette, hogy a meghibásodás a 2. fokozat oxigéntartályában keletkezett. A károk felmérésekor az is kiderült, ऊ) hogy az SLC-40-es olyan súlyosan megsérült, hogy helyreállítása legalább egy évet fog igénybe venni. Egy nappal később a SpaceX be is jelentette, hogy az LC-39/A-hoz költöznek. A négyhónapos hibaelhárítás befejezése után a SpaceX Corporation Falcon-9 v1.2 rakétája 2017. január 14-én tért vissza a szolgálatba; $10 \mathrm{db}$ IridiumNEXT mủholdat állított Föld körüli pályára.

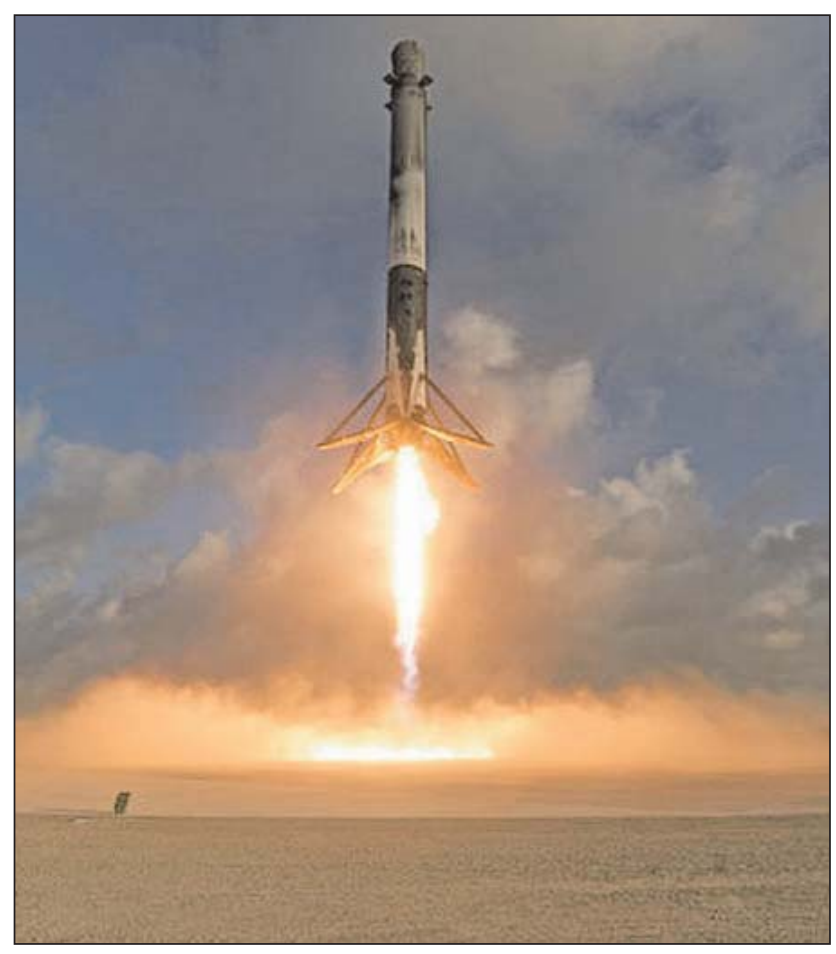

17. ábra. Sikeres visszatérés Cape Canaveral-re (SpaceX)

2016. április 30-án a SpaceX kiadta az új teljesítményadatokat a továbbfejlesztett rakétáról. A kétlépcsős Falcon-9 v1.2 starttömege - a hasznos teher nélkül - 564 tonnára emelkedett, tolóereje 7609 kN-ra nőtt. Ez a rakéta már 22,8 tonna hasznos terhet tud $28,5^{\circ}$-os alacsony Föld körüli pályára, 8,3 tonnát $27^{\circ}$-os geoszinkron átmeneti pályára 5,5 tonnát ugyanilyen pályára állítani; ez utóbbit az 1 . fokozat visszatérése esetén. A Falcon-9 v1.2 felbocsátási költsége 62 millió dollár.

2017 elejére világossá vált, hogy a SpaceX ezt a továbbfejlesztett változatot „Falcon-9 Block 5”-nek nevezte el. A Block 5 fokozattal ellátott rakéta alkalmas a Dragon Commercial Crew űrhajó Föld körüli pályára való állítására - pl. a Nemzetközi Ürállomáshoz - azaz a Dragon űrhajón üzleti céllal utazhatnak hivatásos és fizető űrhajósok, űrutasok. Az első Falcon-9 Block 5 felbocsátása 2017 végén megtörtént.

Megfigyelők szerint 2017 elejéig „Falcon-9 Block 3”asak repültek, azaz a Block 3-as a Falcon-9 v1.2 változatának volt tekinthető. A „kimaradó” Block 4-es azonosítása 2017 elejéig nem történt meg, valószínűleg még csak a SpaceX mérnökei ismerik.

Elon Musk hangzatos kijelentése között szerepelt a Mars utazás lehetősége is. Ami figyelemre méltó ebben az, hogy az ő rakétáival juthatnak el az első emberek a vörös bolygóra. Tény, hogy a Falcon-9-es első fokozatának hajtóműves visszatérése előrelépést jelent a marsi leszállás megvalósításában. Azt pedig, hogy ki fogja először elérni a Marsot, nagyjából 15-20 év múlva tudhatjuk meg.

\section{FORRÁSOK}

Space Launch Vehicles - http://www.b14643.de/

Spacerockets_2/United_States_1/Falcon-9/Description/ Frame.htm;

Günter Space Page - http://space.skyrocket.de/doc_lau/ falcon-9.htm 